\title{
Planning the amount of construction work by modelling the industry competitive field
}

\author{
Margarita Panteleeva ${ }^{1, *}$, and Svetlana Borozdina ${ }^{1}$ \\ ${ }^{1}$ Moscow State University of Civil Engineering, Yaroslavskoe shosse, 26, Moscow, 129337, Russia
}

\begin{abstract}
The article gives the author's interpretation of concepts such as the model of competitive field and competitive market conditions in the field, and shows how to quantify the competitive field provided adequate statistical base for the operation of enterprises in market competition. The authors offer a competitively construction company with a model of the competitive field, which gives the following definition: a model of a competitive field is a graph crossing function of the life cycle of concrete products construction companies. However, the model cannot afford to manage the process, it only helps to visualize the situation. To control you need to select a specific element of the model, which can be quantified. The authors make it through the competitive field, which is defined as a closed path created by the intersection of functions depending on the market price of the construction product by product positioning in the market of the time. For a quantitative analysis of the competitive field size must use the main economic-mathematical methods and types of statistical analysis of competition.
\end{abstract}

\section{Introduction}

Organizational and structural features of the development of integrated programs are not sufficiently addressed in the economic literature. N Only some studies on this matter expressed fairly common situation. For example: "Integrated state program designed for the effective implementation of the most important objectives of social development, solving the most complex public issues, which, based on analysis of the current development trends in the industry and inter-industry complexes, cannot be solved without specially organized structural change and a number of special activities required to overcoming the inertia of established relationships and proportions set out the organizational structure of the planning and management process. " Analyze the features of the development of integrated programs from the standpoint of the development of the financial and economic plan of activity of the building enterprise. [1]

For the organization and planning of building competitiveness is one of the most important characteristics that ensure the realization of the strategic objectives of enterprises and stable development of the industry as a whole. To achieve the success of a construction company in the market conditions of transition to the innovation level is possible only

\footnotetext{
*Corresponding author: anteikom@yandex.ru
} 
under condition of hard work of strategic management, which is necessary to make a complete restructuring of the previously used methods for sustainable situation of the company in a competitive environment.

\section{Methods}

Making any kind of financial and business plans is based on a multi-level system.

We describe its main features. It consists of a set of interacting elements, which in the operation have to make planning decisions. Under elements understood organizations or entities involved in the development of financial and business plans, for example, the various business units, departments or subsidiaries. Elements of the system are arranged hierarchically in the sense that some of them are managing others.

Between the elements of the multi-level planning, there are vertical and horizontal connections. Vertical communication caused by processes focused coordination elements of the lower levels of the relevant elements of the higher levels of the hierarchy. As a rule, there are vertical links between elements of adjacent levels. Horizontal communication correspond to the exchange of information between elements of the same level.

Each element of the planning system is developing a plan for your facility (department, division, etc.), and this element of the subordinate cells at lower levels focused on the "parts" of the object. Isolation of "parts" can occur on the territorial, industrial, functional features and combinations thereof, for example, an element can be engaged in the development plan for the development of the system of material incentives for individual employees of the subsidiary.

When moving from the bottom-up through the levels of the hierarchy there is a consistent increase in the loss of generality. Each item views its object in a more general way than it collectively considered subordinate cells and developed part of the plan concerns with respect to the more general characteristics of the object, and the cells subordinate plans to concretize it for their "parts". Accordingly, the interaction of elements of different levels have a certain character. The information provided to a certain element, describes the plan developed by the subordinate unit in a fairly general way in terms of the most important for the parent side, i.e. in the transition to higher levels of the hierarchy there is the aggregation of information. Thus, any member may develop a production plan to twenty kinds of products (in kind) and top report only calculated in terms of value index of total production. [2, 3]

In turn, control signals and concern about the general aspects of the elements of the lower levels. Indicators operated by elements of the planning system can be divided into three groups: input, output and internal (intermediate).

It includes input indicators that reflect the state of this element of the subordinate cells of lower hierarchy level, as well as control parameters by which higher-level item affects the behavior of this element of the system. By the weekend are indicators that carry information element of a higher level on the state of the element, as well as control parameters by which the element affects the behavior of the subordinate cells of a lower level of hierarchy. Internal indicators, along with input and output in some detail in terms of the element describes the corresponding planning object.

They define, for example, the extent to which in this or that version of the plan are implemented target element, serve as the basis for the formation of the output indicators. Internal metrics are not exposed to the direct effects from higher levels. The whole set of indicators should comprehensively describe the planned system of activities for the development of the building enterprise, assess its effectiveness and the consequences of the implementation of various programs. Table 1 lists the main groups of indicators that operate on a multi-level planning system elements (horizontal links are not considered). [4] 
Table 1.The main groups of indicators elements multilevel planning system.

\begin{tabular}{|c|c|c|}
\hline $\begin{array}{c}\text { The name groups of } \\
\text { indicators }\end{array}$ & Informationsources & Directionofuse \\
\hline $\begin{array}{c}\text { Inputs informative } \\
\text { indicators }\end{array}$ & $\begin{array}{c}\text { Elements below-standing } \\
\text { level through vertical } \\
\text { information links }\end{array}$ & $\begin{array}{c}\text { They are used in the cell, both } \\
\text { independently and as a basis for the } \\
\text { development of internal and output } \\
\text { indicators }\end{array}$ \\
\hline $\begin{array}{c}\text { Inputs control } \\
\text { indicators }\end{array}$ & $\begin{array}{c}\text { Elements of the above- } \\
\text { standing level through } \\
\text { vertical coordination bonds }\end{array}$ & $\begin{array}{c}\text { Used in the element for the } \\
\text { implementation of the original work, } \\
\text { and to adjust the calculation of earlier }\end{array}$ \\
\hline $\begin{array}{c}\text { Internal indicators } \\
\text { Developedintheelement }\end{array}$ & $\begin{array}{c}\text { They are used in the cell, both } \\
\text { independently and to develop output } \\
\text { indicators }\end{array}$ \\
\hline $\begin{array}{c}\text { The output } \\
\text { informative } \\
\text { indicators }\end{array}$ & Developedintheelement & $\begin{array}{c}\text { Serve as the basis for the formation of } \\
\text { the parent messages about the state of } \\
\text { the system components }\end{array}$ \\
\hline $\begin{array}{c}\text { The output control } \\
\text { indicators }\end{array}$ & Developedintheelement & $\begin{array}{c}\text { Serve as the basis for the formation of } \\
\text { control actions (coordinating signals) } \\
\text { on the elements subordinate hierarchy } \\
\text { level }\end{array}$ \\
\hline
\end{tabular}

One of the main characteristics of multi-level systems is known to aggregate the information on the levels of the hierarchy. Output figures coming to the higher-level element, describe the state of the child in a fairly general way in terms of the most important element for a higher level parties. Accordingly, the coordinate signals relating to the most common aspects of the elements of a lower level.

This creates a relative freedom in the activity of elements of the planning system. From the values of output parameters cannot be set the exact value of intermediate input information and indicators, and thus directly control them. Selection of the final values of the intermediate and output control parameters is represented by the elements of the planning system, and manifests what their role as crucial points in the process of drawing up the plan. $[5,6,7]$

Suppose, for example, an element of the system is developing a plan for the development of pits in the whole object. Top it reports only the total production, measured in cubic meters (output component). From the lower cells it receives evidence of the alleged volume of production on soil types separately (input parameters). Then the indicators of production volumes of each type of soil on the whole objects (assuming that their cell counts) are internal. In interactions, respective horizontal links are not going to stop.

The right to choose the final value of the internal indicators (as well as output control) belongs to the element of the system, of course, if they are not obtained from the input control parameters on the basis of direct payments. Input control indicators, imposing restrictions on the possible values for the intermediate, as a rule, leave this element of a certain freedom in the choice of their values, that is, for a multi-level planning is characterized by the relative decentralization of decision-planning decisions. 
All elements of the multi-level planning in the course of their activities should be guided by (and guided) defined objectives. On the basis of these objectives are built both formal and informal criteria to evaluate various options for the corresponding planning decisions and to choose the most appropriate and effective.

The process of financial and economic plan of multilevel system can be presented simplistically as follows. Each element of the wasp-mented development plan for its object, the elements share performance information. performed both original works and adjusted solutions and the calculations made earlier on the basis of these reports. When the process ends, in each element is "ready" of the financial and economic plan concerning the relevant object to it.

These parts are linked with each other by input and output indicators. Thus, the finished financial plan is presented as a set of parts, linked on the inputs and outputs, each of which is located at an appropriate development plan element of the system.

Thus, in the above described general multilevel scheduling system. One of its main features is the relative decentralization of decision-making of plan that can significantly reduce the amount of information circulating in the system, the activity of the cells to give a creative character, improve their individual responsibility for the quality of the plan. At the same time, the relative independence of the activity of the cells creates the possibility of inconsistency of certain parts of the plan, which puts high demands on the coordination mechanism.

In the course of drawing up the plan can meet the problem, an effective solution which is within the current planning system is either impossible or impractical due to significant uncertainty or planning decisions necessary coordination cycles. comprehensive programs can be developed to solve these problems. In developing the program planning item may violate established in the system functions and the distribution assumes the realization of the functions of subordinate hierarchy of lower-level cells, that is, there is a certain centralization of functions for the development of the plan. Changes can have a different character. Perhaps, for example, that for a certain part of the planning object corresponding to a given cell, the parent element assumes a function of the decision on the choice of directions of its development, leaving the cell information function related to finding possible alternatives. And it is possible that this part of the object is completely removed from the sphere of activity of the cell, and a plan developed by the parent for her. However, in any case, the decision function is centralized.

As a result of the internal indicators coming out of the control of the cells at lower levels of the hierarchy, subordinates "and software to develop" element, and it is able to consider the unity of the system of indicators, which sufficiently complete to solve standing in front of him scheduled task really complex. $[8,9]$

If the non-program part of the plan appear as a relatively isolated, agreed only on the inputs and outputs of the blocks, each of which is located at the respective planning cell, the program in the form of a single set of interrelated indicators "is" an element, that it develops. Program if necessary, can penetrate several hierarchical levels, covering different number of elements of each level. In connection with this it is possible to allocate the vertical and horizontal aspects of centralization of functions. In the former case, the cells are centralized functions of several successive levels; in the second - a function of a number of cells of the same level.

The program is usually present both aspects. $[10,11]$

In the area described problems finding and development of effective methods and tools for strategic and practical management of competitiveness of construction enterprises is of great theoretical and practical interest as it contributes to the quality and management of accessibility, ensures a steady increase of efficiency of the considered construction companies and creates favorable conditions for the development of the industry as a whole. 


\section{Results}

The authors offer a competitively construction company with a model of the competitive field, which gives the following definition: a model of a competitive field is a graph crossing function of the life cycle of concrete products construction companies.

However, the model cannot afford to manage the process, it only helps to visualize the situation. To control you need to select a specific element of the model, which can be quantified. The authors make it through the competitive field, which is defined as a closed path created by the intersection of functions depending on the market price of the construction product by product positioning in the market of the time.

For a quantitative analysis of the competitive field size must use the main economicmathematical methods and types of statistical analysis of competition, which are presented in Tables 2 and 3, respectively. Note that Table 2 shows the quantitative analysis methods that allow only assume the relationship between the major determinants of the competitive environment. Table 3, in turn, describes the types of statistical analyzes that combine quantitative and qualitative indicators of the competitive field.

Table 2.The main economic-mathematical methods to assess competition. [12]

\begin{tabular}{|c|c|c|}
\hline Method name & Description of the method & Examples of marketing tasks \\
\hline $\begin{array}{c}\text { Simple } \\
\text { extrapolation }\end{array}$ & $\begin{array}{l}\text { This implies the construction of a } \\
\text { model that determines the general } \\
\text { direction of development, the basic } \\
\text { tendency (trend) of time series. }\end{array}$ & $\begin{array}{l}\text { Establishment of the basic trends } \\
\text { of the dynamics of demand for } \\
\text { construction products market } \\
\text { objects. }\end{array}$ \\
\hline $\begin{array}{l}\text { Regression } \\
\text { analysis }\end{array}$ & $\begin{array}{l}\text { It combines practical methods of } \\
\text { research the relationship between the } \\
\text { averaged values based on statistical } \\
\text { data. The regression dependence is } \\
\text { defined in cases where one of the } \\
\text { variables is classified as an } \\
\text { independent, and the other - as a } \\
\text { dependent. }\end{array}$ & $\begin{array}{l}\text { 1. Determination of the proportion } \\
\text { of variation in sales, which can be } \\
\text { explained by the level of prices. } \\
\text { 2. The ranking factors such as } \\
\text { price. } \\
\text { 3. Preparation of forecast } \\
\text { estimates the number of types of } \\
\text { construction products that } \\
\text { consumers can buy, depending on } \\
\text { income. }\end{array}$ \\
\hline $\begin{array}{l}\text { Modeling using } \\
\text { the regression } \\
\text { equation systems }\end{array}$ & $\begin{array}{l}\text { It involves the construction and } \\
\text { evaluation of a system of } \\
\text { interdependent econometric models. }\end{array}$ & $\begin{array}{l}\text { Forecasting demand equilibrium } \\
\text { determined by the supply and } \\
\text { demand curve }\end{array}$ \\
\hline
\end{tabular}

The above methods of economic - mathematical analysis gives the researcher a clear idea about the ways the relationship key determinant of competition, and each of these types of statistical analysis plays a unique role in the process of analyzing the activities of a construction company, but as a rule, researchers are integrating multiple types of analysis to obtain a more expanded end result.

For descriptive analysis it is often the starting point in the process of statistical data analysis. In the descriptive analysis of the calculated baselines that are either used alone or in the future become the basis for further calculations. This may be a description of a typical respondent (gender, age), as well as the consumers' preferences.

Table 3.Types of statistical analysis used to estimate competition. [13]

\begin{tabular}{|c|l|c|c|}
\hline $\begin{array}{c}\text { Analysis } \\
\text { type }\end{array}$ & Description & Example & $\begin{array}{c}\text { Statistic al } \\
\text { quantity }\end{array}$ \\
\hline $\begin{array}{c}\text { Descriptive } \\
\text { analysis }\end{array}$ & Data compression & $\begin{array}{c}\text { Description of a typical } \\
\text { respondent; identification } \\
\text { of correspondence }\end{array}$ & $\begin{array}{c}\text { The average value, } \\
\text { median, mode, } \\
\text { frequency }\end{array}$ \\
\hline
\end{tabular}




\begin{tabular}{|c|c|c|c|}
\hline & & between respondents & $\begin{array}{l}\text { distribution, range, } \\
\text { standard deviation }\end{array}$ \\
\hline $\begin{array}{l}\text { Analysis } \\
\text { logical } \\
\text { conclusions }\end{array}$ & $\begin{array}{l}\text { Defining the } \\
\text { parameters of the } \\
\text { population, testing } \\
\text { of hypotheses }\end{array}$ & $\begin{array}{c}\text { Formation of conclusions } \\
\text { about the general set based } \\
\text { on sample analysis }\end{array}$ & $\begin{array}{c}\text { The standard error } \\
\text { of the null } \\
\text { hypothesis }\end{array}$ \\
\hline $\begin{array}{l}\text { Analysis of } \\
\text { the } \\
\text { differences }\end{array}$ & $\begin{array}{l}\text { Determining } \\
\text { whether there is a } \\
\text { difference } \\
\text { between the two } \\
\text { groups }\end{array}$ & $\begin{array}{l}\text { Statistical significance of } \\
\text { differences between mean } \\
\text { values of the two groups in } \\
\text { the selection }\end{array}$ & $\begin{array}{l}\mathrm{t} \text { - test for } \\
\text { differences }\end{array}$ \\
\hline $\begin{array}{l}\text { Association } \\
\text { analysis }\end{array}$ & $\begin{array}{c}\text { Definingassociatio } \\
\text { ns }\end{array}$ & $\begin{array}{c}\text { Definition of systematic } \\
\text { connectedness between the } \\
\text { two variables }\end{array}$ & $\begin{array}{l}\text { Thecorrelation, } \\
\text { cross-tabulation }\end{array}$ \\
\hline Forecasting & $\begin{array}{c}\text { The forecast is } \\
\text { based on statistical } \\
\text { models }\end{array}$ & $\begin{array}{l}\text { Determine the value of } Y \\
\text { for certain values of } X\end{array}$ & Regression \\
\hline
\end{tabular}

In turn, inferences analysis allows the researcher to make a conclusion with respect to the population based on the sample data. Analysis of the differences is used when the researcher needs to compare the average values in the responses between the samples.

The associative analysis allows you to determine whether two variables with each other and, if related, how. Associative analysis reveals the strength of the bond between the two variables and connection direction (positive and negative) between the two research questions questionnaire. [14] The most difficult type of statistical analysis is considered to forecasting - the definition of future events, based on the data collected. However, the most correct statistical analysis provides consistent use in the study of the basic methods of competition, with each subsequent should be more difficult than the previous one.

Table 4.Analytic functions for statistical forecast. [15]

\begin{tabular}{|l|l|l|}
\hline $\begin{array}{l}\text { The prognostic } \\
\text { curve }\end{array}$ & Function & Description of the phenomenon \\
\hline $\begin{array}{l}\text { The parabola of the } \\
\text { second order }\end{array}$ & $y_{t}=a_{0}+a_{1} t+a_{2} t^{2}$ & $\begin{array}{l}\text { Successfully used when changing } \\
\text { parameter values in the dynamics of the } \\
\text { acceleration (deceleration) }\end{array}$ \\
\hline $\begin{array}{l}\text { The exponential } \\
\text { Easy }\end{array}$ & $y_{t}=a_{0} e^{a_{1} t}$ & $\begin{array}{l}\text { Phenomena are the stages of slow and } \\
\text { rapid development }\end{array}$ \\
\hline Degrees & $y_{t}=a_{0} t^{a_{1}}$ & $\begin{array}{l}\text { The phenomenon of accelerated } \\
\text { development with a predominant }\end{array}$ \\
\hline $\begin{array}{l}\text { The hyperbolic } \\
\text { type I }\end{array}$ & $y_{t}=a_{0}+\frac{a_{1}}{t}$ & $\begin{array}{l}\text { The phenomenon of the prevailing } \\
\text { stages of delayed development }\end{array}$ \\
\hline $\begin{array}{l}\text { The hyperbolic } \\
\text { type II } \\
\text { The hyperbolic } \\
\text { type III }\end{array}$ & $y_{t}=\frac{1}{a_{0}+a_{1} t} ; y_{t}=\frac{t}{a_{0}+a_{1} t}$ & $\begin{array}{l}\text { Wavelets in the development are the } \\
\text { result of the gradual accumulation of } \\
\text { quantitative changes }\end{array}$ \\
\hline The logarithmic & $y_{t}=a_{0}+a_{1} \ln t$ & $\begin{array}{l}\text { The development of events followed by } \\
\text { a slowdown (saturation) }\end{array}$ \\
\hline
\end{tabular}




\begin{tabular}{|l|l|l|}
\hline S-shaped & $y_{t}=e^{a_{0}+a_{1} / t}$ & $\begin{array}{l}\text { The model responds well to changes in } \\
\text { the data, it is able to take into account } \\
\text { the numerous stages of deceleration and } \\
\text { acceleration in the development }\end{array}$ \\
\hline Back logarithmic & $y_{t}=\frac{t}{a_{0}+a_{1} \ln t}$ & Similarly, thefunction 6 \\
\hline Theharmonic & $y_{t}=a_{0}+a_{1} \cos t+a_{2} \sin$ & $\begin{array}{l}\text { It describes the data having a certain } \\
\text { frequency of recurrence, seasonality }\end{array}$ \\
\hline
\end{tabular}

The selected approaches (Table 3 and Table 4) allows the above-defined model for competitive fields present in the form of a contour integral of the second type for scalar functions $f=p(t)$ :

$$
C_{f}=\oint\left[f_{1}(p) d t_{1}+f_{2}(p) d t_{2}+\cdots+f_{n}(p) d t_{n}\right]=\oint_{t_{i}}^{t_{k}} f[t, P(t)] \sqrt{1+\left[P^{`}(t)\right]^{2} d t}(1)
$$

where the:

$f 1(t), \ldots, f n(t)-n$ functions defined on $C f$ contour;

$C f$ (competitivefield) - is a competitive field, or, from the geometric point of view, a closed contour, limited scalar functions $f 1, f 2, \ldots f n$;

$f 1, f 2, \ldots f n$ - functions according to the price of sale of the product positioning time for the nconstruction companies competing in the market environment);

$\mathrm{Pi}$ - the price sale of construction products;

ti - the time during which the company-manufacturer occupies a leading position in the construction market;

fi - is a function of construction products life cycle of i-building enterprise, which depends on the selling price $(\mathrm{Pi})$ and the time (ti), during which the company - manufacturer occupies a leading position in the construction market.

In addition, competitive field area calculation can be performed according to the formula:

$$
S=\frac{1}{2} \oint_{C_{f}} t d P-P d t(2)
$$

\section{Discussion}

Having the dependence (1), it is possible to design a graphical model (Figure 1) formation of a competitive field for the $\mathrm{n}$-th number of construction companies. For an example of a function depending on the price of sale of the time from a large variety of mathematical dependencies (Table 4) take the parabola.

Then the competitive field of four companies-manufacturers of construction products is an area framed in color. 


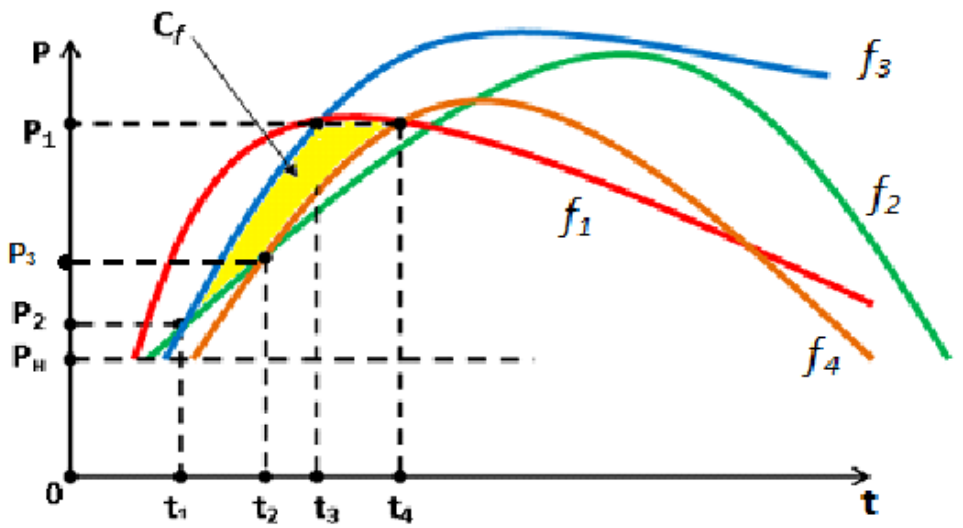

Fig. 1.Graphic model of the competitive field.

Thus, having the correct basis of statistical data on the functioning of the building enterprise in the market, it is possible to forecast the optimum time and price ranges (topt $\epsilon$ $(\mathrm{t} 1 ; \mathrm{t} 4)$; Ropt $\in(\mathrm{P} 1, \mathrm{P} 2))$, under which the company naturally with little effort (reduction of marketing costs) holds a leading market position in a tough competitive environment.

\section{Conclusion}

In conclusion, we note that the currently existing system of production volume planning in a competitive market characterized by a relatively small degree of decentralization in the preparation of sales forecasts. This leads to an excessive overload of the system elements of the upper levels supplied to them the information they are often unable to sufficiently quickly and accurately process that reduces the efficiency of the whole system planning. Changing this situation, of course, possible in the way of strengthening decentralization while improving the coordination mechanism of all the elements of such a system. [16] A role in addressing this issue and will be able to play a complex program that centralizing decision-making on some issues, can afford to weaken the centralization in dealing with others. Then some element of the system part of their routine tasks for which the established coordination mechanism is satisfactory will be decided by non-program, while others - with the help of development programs. At the same time by reducing the flow of information, relevant non-program part of the plan member will pay more attention to planning programs by implementing not only the formal monitoring of their performance, and really considering various options for the implementation of program objectives, comprehensively evaluating them and selecting the most effective.

\section{References}

1. N.G.Verstina, T.N.Kisel, N.N.Taskaeva, E.M.Akimova, Asian Social Science, 11 (14), 169-180, (2015)

2. E.I. Pupyrev, Mekhanizatsiya Stroitel'stva, 6, 8-10 (2002)

3. L.V. Kievskij, PGS, 4, 20-22 (2001)

4. A. Ginzburg, S. Kachanov, International Journal of Applied Engineering Research, 11(3), 1660 - 1665 (2016) 
5. A.Volkov, A. Sedov, P. Chelyshkov,B. Titarenko, G. Malyha, E. Krylov, Research Journal of Pharmaceutical, Biological and Chemical Sciences, 7(3), 2416-2420 (2016)

6. V.S. Kankhva, S.S. Uvarova, S.V. Belyaeva, Procedia Engineering, 165, 1046 - 1051 (2016)

7. I.G. Lukmanova, PGS, 4, 41-47 (2001)

8. I.G. Lukmanova, PGS, 2, 50-54 (2001)

9. D.N. Silka, World Applied Sciences Journal, 31(1), 148-150 (2014)

10. D.N. Silka, Life Science Journal,11( 7), 310 - 313 (2014)

11. M.I. Kamenetskii, N.Y. Yas'kova, Studies on Russian Economic Development, 26 (2), 124-131, (2015)

12. M.I. Kamenetskii, Studies on Russian Economic Development, 24 (3), 249-258 (2013)

13. N.A. Bondareva, M.Ju. Mishlanova, G.A. Syzrancev, S.M. Gorkina, Monitoring rynkanedvizhimosti: metodologija, rezul'taty, zakonomernosti (MGSU, Moscow, 2011)

14. N.G.Verstina, T.S.Meshcheryakova, Biosciences Biotechnology Research Asia, 12(2), 1411-1423 (2015)

15. N.G. Verstina, T.N. Kisel, N.N. Taskaeva, E.M. Akimova, A.V. Fedosina, International Journal of Applied Engineering Research, 10 (20), 41156-41163 (2015)

16. S.S. Uvarova, S.V. Belyaeva, V.S. Kankhva, V.A. Vlasenko, Procedia Engineering, 165, $1317-1322$ (2016) 